\title{
Effect of Water Stress on Growth and Physiology of Tomato (Lycopersicon esculentum Mill.)
}

\author{
Ibrahim A. A. Almohisen* \\ Department of Biology, Faculty of Science and Humanities, Quwayiyah, Shaqra \\ University, P.O. Box 33, Shaqra, 11961, Kingdom of Saudi Arabia
}

\section{Received: $9 / 8 / 2015$}

\begin{abstract}
The effects of drought on physiology of Tomato (Lycopersicon esculentum Mill.) cv., Farida grown in pots were studied. Drought stress was done by irrigating the plants with 80,60 and $40 \%$ of water needed to reach soil pot capacity. Nutrients concentrations of the studied tomatoes grown in pots under different irrigation treatments varied according to water stress levels. The effect of water stress treatments on total chlorophyll, chlorophyll a, chlorophyll b and carotenoids resulted in significant increase with treatment $80 \%$ water deficit, then significant decrease in accumulation of pigments in response to water stress under 40 and $60 \%$ water deficit. All water stress treatments had highly significant effect on increasing accumulation of proline content. Drought stress induced different changes in the anti-oxidative enzyme activities, whereas, Ascorpate peroxidase and Catalase increased significantly with water stress from 0.58 and $140.7 \mathrm{Ug}^{-1} \mathrm{FW}$ in control to 4.08 and $414.9 \mathrm{Ug}^{-1} \mathrm{FW}$ in $\mathrm{T} 4$, respectively. In contrary, superoxide dismutase decreased significantly with water stress from 42.36 in $\mathrm{T} 1$, to $31.32,33.54$ and 31.51 in $\mathrm{T} 2$, T3 and $\mathrm{T} 4$, respectively. The results indicate that irrigation treatment with $80 \%$ of pot capacity (T2) was more effective than T3 and T4 from the viewpoint of more efficient water use, which would help to minimize drought damage and keep healthy plants in the same time saving irrigation water by $20 \%$.
\end{abstract}

Keywords: Tomato, Water stress, Nutrients, Antioxidant enzymes, Pigments, Proline.

\section{INTRODUCTION}

Tomato (Lycopersicon esculentum Mill.) is one of the most popular and economically important vegetable crops all over the world. Tomato is an important source of antioxidants including, lycopene, phenolics, and vitamin $\mathrm{C}$ in human diet. The yield and quality of fresh tomato are governed by both genetic factors and environmental conditions. Among the environmental factors, water is a major component affecting plant growth and in turn, fruit quality of tomatoes. Therefore, optimum irrigation and proper drainage are critical to increase tomato yield and quality (Shao et al., 2014). The reduction in growth, yield and quality by water stress has been well documented, although different physiological processes have been put forward to account for this reduction in different species. Although there have been many studies on the effects of water deficit on yield, comparatively few have addressed the relationship among yield, vegetative growth, and physiological responses to different irrigation regimes (Kirnak et al., 2001). Plants experience water stress either when the water supply to their roots becomes limiting, or when the transpiration rate becomes intense. Plants try to adapt to drought stress with an array of biochemical and physiological interventions. Concerning water scarcity our country is dry, high temperature zone and faced with increased competitions for water resources between different sectors (agriculture, industry or domestic consumption). So, economic use of water in irrigation regimes is an essential matter. Optimizing irrigation water management for the crop production could result in increased productivity and water savings. This goal will be realistic only if appropriate strategies are found for water savings and for more efficient water uses in

*E-mail: ibraheem@su.edu.sa agriculture. One important strategy is to better manage water and increase its productivity (Molden, 1997; Molden et al., 2001). It is also necessary to develop new irrigation scheduling approaches, not necessarily based on full crop water requirement, but ones designed to ensure the optimal use of available water. A better understanding of the effects of drought on plants is vital for improved management practices and breeding efforts in agriculture under climate change. Many works were developed over the past couple of decades, covering subjects from plant strategies to control water status under drought, to the physiological and biochemical processes underlying plant response to water deficits (Chaves, 1991; Cornic and Massacci, 1996; Shao et al., 2014). Tomato is regarded as a sensitive crop to water stress, revealing the high correlation between evapotranspiration (ET) and crop production, since ET is a direct measure of crop water loss (Nuruddin et al., 2003). The supply of the required water to the tomato plants is crucial for its growth and economic production, especially in the greenhouse (Aziz et al., 2013)

The present research was carried out to study the effect of drought stress on physiological characters of studied tomato, leaf chlorophyll, carotenoids, proline and enzyme activity, as well as, nutrients uptake.

\section{MATERIALS AND METHODS}

An experiment was carried out during the growing season of 2013 at the Agricultural Experimental and Research Station (Dirab), Faculty of Food and Agricultural Sciences - King Saud University, near Riyadh $\left(24^{\circ} 42^{\prime} \mathrm{N} 44^{\circ} 46^{\prime} \mathrm{E}, 600\right.$ Alt.). The seeds of Tomato (Lycopersicon esculentum Mill.) cv., Farida were planted at nursery in glass house tell seedling 
reach $15 \mathrm{~cm}$ height (three foliage leaves) then transported to pots size $30 \mathrm{~cm}$ filled with sandy loam (1:1) in the outfield. Plants were fertilized by fifteen grams of compound (Nitrogen, Phosphorus and Potassium) N:P:K 15:15:15 to every pot twice in the life of tomato plants, the first one was before the beginning of flower stage and the second was after three weeks of the first one. Irrigating treatments started on $1^{\text {st }}$ of March
2013 and the harvest were done on $1^{\text {st }}$ of June 2013. Randomized complex block design was used. Soil physical and chemical properties measured according to (Cassel and Nilsen, 1986; Gee and Bander, 1986; Rhoades, 1982). Also, chemical properties of irrigation water were estimated according to (Richards, 1968) as shown in Table (1).

Table (1): Physical and chemical properties of soil and irrigation water.

\begin{tabular}{|c|c|c|c|}
\hline & & Irrigation water & Soil \\
\hline \multicolumn{2}{|r|}{ pH } & 7.1 & 8.40 \\
\hline \multicolumn{2}{|r|}{$\mathrm{EC}(\mathrm{dS} / \mathrm{m})$} & 7.0 & 9.1 \\
\hline & $\mathrm{Ca}^{2+}$ & 3.6 & 35.0 \\
\hline Soluble Cations & $\mathrm{Mg}^{2+}$ & 0.5 & 19.5 \\
\hline \multirow[t]{3}{*}{$\mathrm{meq} / \mathrm{L}$} & $\mathrm{Na}^{+}$ & 3.2 & 34.3 \\
\hline & $\mathbf{K}^{+}$ & 0.114 & 2,0 \\
\hline & $\mathrm{CO}_{3}^{2-}$ & 0 & 0.125 \\
\hline \multirow[t]{6}{*}{$\begin{array}{l}\text { Soluble Anions } \\
\mathrm{meq} / \mathrm{L}\end{array}$} & $\mathrm{HCO}_{3}^{-}$ & 1.0 & 3.5 \\
\hline & $\mathrm{Cl}^{-}$ & 4.7 & 56.3 \\
\hline & $\mathrm{SO}_{4}^{2-}$ & 1.71 & 21.9 \\
\hline & Saturation point $\%$ & & 27.3 \\
\hline & Pot capacity (at 1 bar) & & 13.6 \\
\hline & Wilting point (at 15 bars) & & 6.8 \\
\hline
\end{tabular}

\section{Irrigation treatments:}

Irrigation treatments depended on measuring the deficit of soil moisture contents from the pot capacity, the potential evaporation was calculated using the Pan evaporation as described by (Doorenbos and Pruitt, 1977). Irrigation treatments included three levels of water deficit stress and the control, as follow control T1 (100\% pot capacity), T2 (80\% pot capacity), T3 $(60 \%$ pot capacity) and T4 (40\% pot capacity) respectively.

Nutrient elements were estimated according to (Bock, 1978). Regarding to Chlorophyll and carotenoid content, the extraction of leaf pigments was performed with $80 \%$ acetone, and the absorbance at 663 and 645 $\mathrm{nm}$ was measured with an Ultrospec 2100 pro spectrophotometer (Amersham Biosciences). Total carotenoid content, chlorophyll a, chlorophyll b, and total chlorophyll quantities were calculated according to the method of (Arnon 1949) using the following formula:

Total Chl $(\mathrm{a}$ and $\mathrm{b})(\mathrm{mg} / \mathrm{l})=20.2\left(\mathrm{~A}_{645}\right)+8.02\left(\mathrm{~A}_{663}\right)$

Chl a $(\mathrm{mg} / \mathrm{l})=12.7\left(\mathrm{~A}_{663}\right)-2.69\left(\mathrm{~A}_{645}\right)$

Chl b $(\mathrm{mg} / \mathrm{l})=22.9\left(\mathrm{~A}_{645}\right)-4.68\left(\mathrm{~A}_{663}\right)$

$\operatorname{Car}(\mathrm{mg} / \mathrm{l})=\mathrm{A}_{480} \times 200$

The pigment concentration was calculated in $\mathrm{mg} / \mathrm{g} \mathrm{FW}$ of samples.

Extraction and estimation of free proline were conducted according to the procedures described by (Bates et al., 1973). Plant tissues $(0.5 \mathrm{~g})$ were homogenized with $5 \mathrm{ml}$ of $3 \%$ sulfosalicylic acid and the homogenates were centrifuged at $3000 \times \mathrm{g}$ for 20 min. In a test tube, $1 \mathrm{ml}$ of the supernatant was mixed with $1 \mathrm{ml}$ acid ninhydrin reagent and $1 \mathrm{ml}$ of glacial acetic acid and incubated in $100^{\circ} \mathrm{C}$ in water bath for $1 \mathrm{~h}$, 
and then the absorbance at $520 \mathrm{~nm}$ was determined. Free proline content in sample is estimated by referring to a standard curve made from known concentrations of proline and the results were expressed as $\mu$ mol proline $\mathrm{g}^{-1} \mathrm{FW}$ (fresh weight).

For extraction and analysis of antioxidant enzymes, leaf samples ( $0.5 \mathrm{~g}$ fresh weight, $\mathrm{FW})$ were homogenized in $3 \mathrm{ml}$ extraction buffer $(0.1 \mathrm{M}$ potassium phosphate buffer $(\mathrm{pH} 7.0), 1 \mathrm{mM}$ EDTA, $0.05 \%$ Triton $\mathrm{X}-100$ ) in a pre-chilled pestle and mortar, centrifuged at $15,000 \mathrm{~g}$ for $20 \mathrm{~min}$ at $4^{\circ} \mathrm{C}$. The supernatant was used for the estimation antioxidant enzyme activities. Superoxide dismutase activity (SOD EC 1.15.1.1) activity was estimated by the ability of this enzyme to inhibit the photochemical reduction of nitro blue tetrazolium salt (NBT). The SOD activity was measured at $560 \mathrm{~nm}$ according to the method of (Beyer and Fridovich, 1987) and the assays were carried out at $25^{\circ} \mathrm{C}$. The final assay volume of $3 \mathrm{ml}$ contained $50 \mathrm{mM}$ Tris-HCl buffer ( $\mathrm{pH}$ 7.8), $33 \mu \mathrm{M}$ NBT, $10 \mathrm{mM}$ Lmethionine, $0.66 \mathrm{mM}$ disodium EDTA, $0.0033 \mathrm{mM}$ riboflavin and $50 \mu \mathrm{l}$ of supernatant. Reaction was started under fluorescent light for 15 minutes by adding $10 \mu \mathrm{l}$ of riboflavin solution. One unit of SOD was defined as the amount of enzyme activity that inhibited the photo reduction of NBT to blue formazan by $50 \%$. The SOD activity of each extract was expressed as Ug-1 FW. Peroxidase (POX) activity was estimated by the method of (Sakharov and Ardila, 1999). Peroxidase enzyme activity was determined by the oxidation of guaiacol in the presence of $\mathrm{H}_{2} \mathrm{O}_{2}$. The increase in absorbance was recorded at $470 \mathrm{~nm}$ for $1 \mathrm{~min}$ with a spectrophotometer. The reaction mixture contained 50 $\mu \mathrm{l}$ of $28 \mathrm{mM}$ guaiacol, $900 \mu \mathrm{l}$ of $50 \mathrm{mM}$ potassium phosphate buffer ( $\mathrm{pH} \mathrm{6.0),} 50 \mu$ of $5 \mathrm{mM} \mathrm{H}_{2} \mathrm{O}_{2}$, and 10 $\mu 1$ of crude extract. POX activity of the extract was expressed as the POX $\mathrm{Ug}^{-1} \mathrm{FW}$. Catalase (CAT EC 1.11.1.6) activity was measured spectrophotometrically according to the method of (Aebi, 1983) The disappearance of $\mathrm{H}_{2} \mathrm{O}_{2}$ at $240 \mathrm{~nm}$ in a reaction mixture containing $50 \mathrm{mM}$ sodium phosphate buffer $(\mathrm{pH} 7.0)$, $20 \mathrm{mM} \mathrm{H} \mathrm{O}_{2}$ and $5 \mu \mathrm{l}$ of supernatant. The decrease in the absorption was followed for $1 \mathrm{~min}$ at $240 \mathrm{~nm}$, and 1 mmol $\mathrm{H}_{2} \mathrm{O}_{2}$ oxidized $\mathrm{ml}^{-1} \min ^{-1}$ was defined as $1 \mathrm{U}$ of CAT activity. Ascorbate peroxidase (APX EC 1.11.1.11) activity was measured according to the methods of (Wang et al., 1991). The reaction mixture contained $50 \mathrm{mM}$ potassium phosphate buffer $(\mathrm{pH} 7.0)$, $0.5 \mathrm{mM}$ ascorbic acid, $0.1 \mathrm{mM}$ hydrogen peroxide, and $20 \mu \mathrm{l}$ of enzyme extract in a total volume of $1 \mathrm{ml}$. The concentration of oxidized ascorbate was calculated by the decrease in absorbance at $290 \mathrm{~nm}$. The absorption coefficient was $2.8 \mathrm{mM}^{-1} \mathrm{~cm}^{-1}$. One unit of APX was defined as $1 \mathrm{mmol} \mathrm{ml}^{-1}$ ascorbate oxidized $\mathrm{min}^{-1}$.

Data obtained were subjected to statistical Analysis Of Variance (ANOVA), according to (Gomez and Gomez, 1984). Averages of the main effects were compared using the revised Least Significant Difference test (LSD) at 0.05 level of probability. Computations and statistical analysis were done using SAS.

\section{RESULTS AND DISSCUSION}

Studied plants content of Potassium (K), Phosphorous (P) and Nitrogen (N) were measured, Table (2). Results show that highest average of potassium (11.37 and $11.33 \mathrm{mg} / \mathrm{g} \mathrm{DW}$ ) was obtained from irrigation treatment with $60 \%$ and $100 \%$ of pot capacity (T3 and T1 treatments), while the lowest $(03.14 \mathrm{mg} / \mathrm{g} \mathrm{DW})$ was recorded by the irrigation treatment with $40 \%$ of pot capacity (T4). (Farghali et al., 1988) found that total $\mathrm{K}+$ content in Cotton seedlings roots and aerial parts increased progressively with decreasing water stress, particularly under light condition. There was significant difference in phosphorous content between treatments, and the highest was in T4 $(58.37 \mathrm{mg} / \mathrm{g} \mathrm{DW})$, while the lowest was in T3 $(28.77 \mathrm{mg} / \mathrm{g} \mathrm{DW})$. Similar trend was obtained with carbon content and nitrogen percentage. The effect of water stress treatments on total chlorophyll, chlorophyll a, chlorophyll $\mathrm{b}$ and carotenoids resulted in significant (at $\mathrm{P} \leq 0.05$ ) starting with increase in accumulation of pigments with treatment two (irrigation with $80 \%$ of pot capacity) then tend to decrease as response to increasing water stress. Total chlorophyll was $(0.84,1.71,0.56$, and $0.50 \mathrm{mg} / \mathrm{g} \mathrm{FW})$ in T1, T2, T3 and $\mathrm{T} 4$ respectively. Regarding to chlorophyll a data obtained were $(0.60,1.18,0.41$ and $0.94 \mathrm{mg} / \mathrm{g} \mathrm{FW})$ for $\mathrm{T} 1, \mathrm{~T} 2, \mathrm{~T} 3$ and $\mathrm{T} 4$ respectively. While, chlorophyll b was $0.23,0.53,0.15$ and $0.21 \mathrm{mg} / \mathrm{g} \mathrm{FW}$ for T1, T2, T3 and T4, respectively. (Kirnak et al., 2001) found that total chlorophyll content in water stress treatment was reduced by $55 \%$ compared to control treatment. Carotenoids decreased in response to water stress from $0.53 \mathrm{mg} / \mathrm{g} \mathrm{FW}$ in T2 to 0.15 and $0.21 \mathrm{mg} / \mathrm{g} \mathrm{FW}$ in the $\mathrm{T} 3$ and $\mathrm{T} 4$ treatments.

The data of analysis of variance showed that, all water stress treatments had highly significant effect on increasing accumulation of proline content. Data showed that proline was $4.36,7.14,10.33$ and 8.36 $\mu \mathrm{mol} \mathrm{g}^{-1} \mathrm{FW}$ in $\mathrm{T} 1, \mathrm{~T} 2, \mathrm{~T} 3$ and $\mathrm{T} 4$ respectively. In response to water stress, proline accumulation generally occurs in the cytosol where it plays significant role in cytoplasmic osmotic adjustment (Anjum et al., 2012). In this study, higher level of proline accumulation in T2 over T3 and T4 enabled the water-stressed plants to maintain low water potentials.

Data in Table (2) show the effect of three water stress treatments on four enzymes content in studied tomatoes plants. Peroxidase was $46.54 \mathrm{Ug}^{-1} \mathrm{FW}$ in control treatment (T1), in treatment two (T2, 20\% water deficit) Peroxidase was $53.82 \mathrm{Ug}^{-1} \mathrm{FW}$, while it decreased dramatically (8.61 and $\left.5.26 \mathrm{Ug}^{-1} \mathrm{FW}\right)$ in $\mathrm{T} 3$, (40\% water deficit) and T4 $(60 \%$ water deficit). Ascorpate peroxidase and Catalase increased significantly with water stress from 0.58 and $140.7 \mathrm{Ug}^{-1}$ FW in control to 4.08 and $414.9 \mathrm{Ug}^{-1} \mathrm{FW}$ in $\mathrm{T} 4$ respectively. In contrary, superoxide dismutase decreased significantly with water stress from 42.36 in $\mathrm{T} 1$, to $31.32,33.54$ and 31.51 in $\mathrm{T} 2, \mathrm{~T} 3$ and $\mathrm{T} 4$ respectively. Drought stress induced different changes in the anti-oxidative enzyme activities (Anjum et al., 2012). Moreover, it has been reported that peroxidase, 
and catalase activities showed an increase or maintenance in the early phase of drought and then a decrease with progression of water stress. It is conspicuous that higher levels of antioxidants are related to plant drought tolerance (Tahi et al., 2008). Superoxide dismutase is considered to form the first line of protection against reactive oxygen species (ROS), which catalyzed the superoxide radical $\left(\mathrm{O}_{2}^{-}\right)$to $\mathrm{O}_{2}$ and $\mathrm{H}_{2} \mathrm{O}_{2}$ which are further quenched by diverse antioxidant enzymes.
From the results, it can be concluded that there are different physiological changes in response to drought stress treatments. The results indicate that irrigation treatment with $80 \%$ of pot capacity (T2) was more effective than T3 and T4 from the viewpoint of more efficient water use, which would help to minimize drought damage and keep healthy plants in the same time saving irrigation water by $20 \%$.

Table (2): Some physiological characters of studied tomato in response to water deficit.

\begin{tabular}{|c|c|c|c|c|c|c|c|c|c|c|c|c|c|}
\hline \multirow{2}{*}{ Treatments } & $\mathbf{K}$ & $\mathbf{P}$ & C & $\begin{array}{c}\mathbf{N} \\
(\mathbf{0})\end{array}$ & \multirow{2}{*}{ 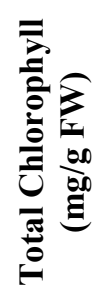 } & \multirow{2}{*}{ 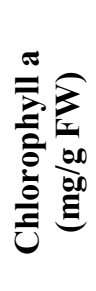 } & \multirow{2}{*}{ 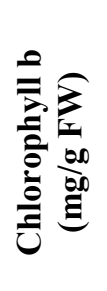 } & \multirow{2}{*}{ 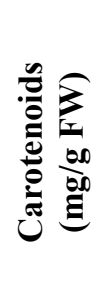 } & \multirow{2}{*}{ } & \multirow{2}{*}{ 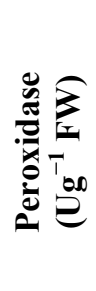 } & \multirow{2}{*}{ 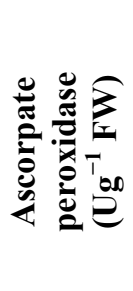 } & \multirow{2}{*}{ ل } & \multirow{2}{*}{ 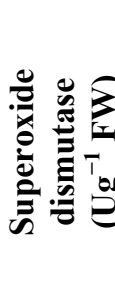 } \\
\hline & \multicolumn{3}{|c|}{ (mg/g DW) } & & & & & & & & & & \\
\hline T1 & 11.33 & 44.50 & 37.33 & 5.44 & 0.84 & 0.60 & 0.23 & 6.03 & 04.36 & 46.54 & 0.58 & 140.7 & 42.36 \\
\hline $\mathbf{T} 2$ & 03.47 & 36.20 & 33.57 & 5.36 & 1.71 & 1.18 & 0.53 & 8.97 & 07.14 & 53.82 & 0.69 & 119.2 & 31.32 \\
\hline T3 & 11.37 & 28.77 & 35.23 & 3.69 & 0.56 & 0.41 & 0.15 & 5.94 & 10.33 & 08.61 & 1.27 & 126.8 & 33.54 \\
\hline T4 & 03.13 & 58.37 & 39.73 & 5.75 & 0.50 & 0.29 & 0.21 & 7.03 & 08.36 & 05.26 & 4.08 & 414.9 & 31.51 \\
\hline $\begin{array}{l}\text { L.S.D. at } \\
0.5 \%\end{array}$ & 0.410 & 0.440 & 1.555 & 1.44 & 0.089 & 0.276 & 0.090 & 0.088 & 0.209 & 0.220 & 0.166 & 1.06 & 0.618 \\
\hline
\end{tabular}

\section{REFERENCES}

Aebi, H. (1983). Catalase. In: Methods of Enzymatic Analysis. Bergmeyer, H. (ed.), pp. 273-277. Verlag Chemie, Weinheim, Adamse.

Arnon, D. I. (1949). Copper enzymes in isolated chloroplasts. Polyphenol oxidase in Beta vulgaris. Plant Physiology, 24: 1-15.

Anjum, S. A., M. F. Saleem, L. Wang, M.F. Bilal and A. Saeed (2012). Protective role of glycinebetaine in maize against drought-induced lipid peroxidation by enhancing capacity of antioxidative system. Australian Journal of Crop Science, 6(4): 576-583.

Aziz, S. A., S. T. Ahmad, B. A. Rasheed, H. B. Sharef and D. H. Talb (2013). The impacts of deficit irrigation levels and intervals on tomatoes and Eggplants yield in unconditions plastic house. Journal of Zankoy Sulaimani-Part A (JZS-A), 15(2): 2 .

Bates, L. S., R. P. Waldren and I. D. Teare (1973). Rapid determination of free proline for water stress studies. Plant Soil, 39: 205-207.

Beyer, W. F. J. and I. Fridovich (1987). Assaying for superoxide dismutase activity: Some large consequences of minor changes in conditions. Analytical Biochemistry, 161: 559-566.

Bock, R. A. (1978). Handbook of Decomposition Methods in Analytical Chemistry. International Textbook Co, Glasgow Scotland.

Cassel, D. K. and D. R. Nilsen (1986). Field capacity and available water capacity. In: Methods of Soil Analysis part 1- Physical and Mineralogical Methods $2^{\text {nd }}$ edition. Klute (ed.)., pp. 901-926. American Society of Agronomy and Soil Science Society of America, Inc. Madison W1.

Chaves, M. M. (1991). Effects of water deficits on carbon assimilation. Journal of Experimental Botany, 42(1): 1-16.

Cornic, G. and A. Massacci (1996). Leaf photosynthesis under drought stress. In: Photosynthesis and the Environment. Advances in Photosynthesis and Respiration. N. Baker (Editor), pp. 347-366. Springer Netherlands,

Doorenbos, J. and W. O. Pruitt (1977). Crop water requirements. Irrigation and Drainage. Paper, No. 24. F.A.O., Rome.

Farghali, K. and H. El-Sharkawi (1988). Interactive effects of NPK nutrients, water potential and 
irradiance on contents of potassium and phosphate in cotton seedlings. Phyton, 28: 171181.

Gee, G. W. and J.W. Bander (1986). Partical-size analysis. In: Methods of Soil Analysis, part 1Physical and Mineralogical Methods, $2^{\text {nd }}$ edition. Klute (ed.), Pp. 383-411. American society of agronomy, Inc., and Soil Science Society of America, Inc. Madison, W1.

Gomez, K. A. and A. A. Gomez (1984). Statistical Procedures for Agricultural Research. WileyInterscience, USA.

Kirnak, H., C. Kaya, I. TAS and D. Higgs (2001). The influence of water deficit on vegetative growth, physiology, fruit yield and quality in eggplants. Bulg. J. of Plant Physiol., 27(3-4): 34-46.

Molden, D. (1997). Accounting for water use and Ppoductivity (IIMI) IX, $16 \mathrm{p}$. SWIM paper 1, International Irrigation Management Institute, Colombo, Sri Lanka.

Molden, D. J., R. Sakthivadivel and Z. Habib (2001). Basin-level Use and Productivity of Water: Examples from South Asia, 49.

Nuruddin, M. M., C. A. Madramootoo and G. T. Dodds (2003). Effects of water stress at different growth stages on greenhouse tomato yield and quality. HortScience, 38(7): 1389-1393.
Rhoades, J. D. (1982). Soluble salts. In: Methods of Soil Analysis, part 2. Chemical and Microbiological Properties $2^{\text {nd }}$ edition. A. L. Page, R. H. Page, R. H. Miller and R. Keeney (eds.), Pp. 167-179. American Society of Agronomy, Inc. and Soil Science Society of American. Inc. Madison, W1.

Richards, L. A. (1968). Diagnosis and improvements of saline and alkali soils. Oxford and IBH Pub. Co. Calcutta, India.

Sakharov, I. Y. and G. B. Ardila (1999). Variations of peroxidase activity in cocoa beans during their ripening, fermentation and drying. Food Chemistry, 65: 51-54

Shao, G., M. Wang, N. Liu, M. Yuan, P. Kumar and D. She (2014). Growth and comprehensive quality index of tomato under rain shelters in response to different irrigation and drainage treatments. The Scientific World Journal, 12.

Tahi, H., S. Wahbi, C. El Modafar, A. Aganchich and R. Serraj (2008). Changes in antioxidant activities and phenol content in tomato plants subjected to partial root drying and regulated deficit irrigation. Plant Biosyst, 142: 550-562.

Wang, S. Y., M. Jiao and M. Faust (1991). Changes in ascorbate, glutathione and related enzyme activities during thiodiazuran-induced bud break of apple. Plant Physiology, 82: 231-236.

\section{تأثير الإجهاد المائي على فسيولوجي ونمو نبات الطماطم

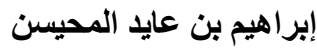 \\ قسم الأحياء -كلية العلوم و الدر استات الإنسانية بالقويعية - جامعة شقر اءئ}

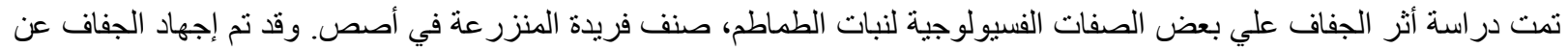

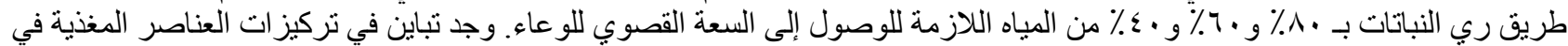

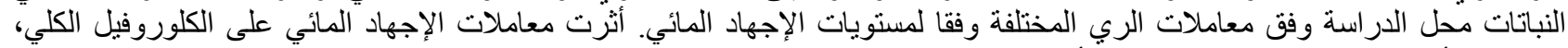

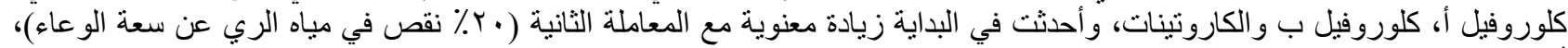

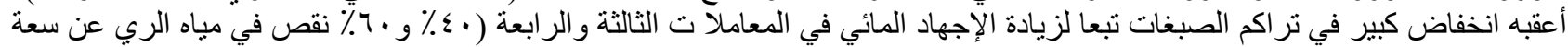

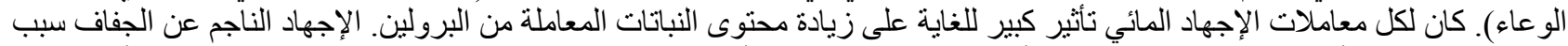

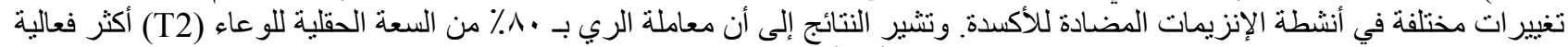

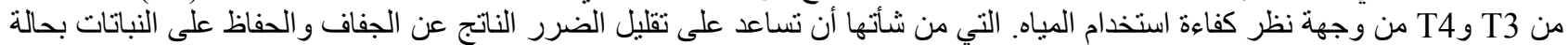

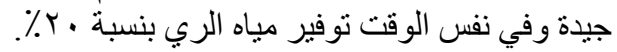

